\title{
1. Introduction: tax competition in international tax policy
}

Literature dealing with international tax policy and practice generally falls into one of three categories: a study of domestic laws relating to cross border tax transactions (for example, Australia's controlled foreign corporation (CFC) or transfer pricing regime); comparative policy or practice analysis using various jurisdictions as case studies (for example, territorial versus worldwide taxation using the US and Japan as examples of the two systems); or a study of the various world organisations and their policy approaches to international tax issues (for example, the Organisation for

Economic Co-operation and Development (OECD) approach to, and work on, tax havens or the competition versus harmonisation debate). ${ }^{1}$

This book focuses on the third category. The OECD continues to work on tax competition as one of the issues in international tax policy and practice. ${ }^{2}$ The

1 Kerrie Sadiq, "The Inherent International Tax Regime and its Constraints on Australia's Sovereignty" (2012) 31 University of Queensland Law Journal 131 at 133.

2 OECD, "Harmful Tax Competition-An Emerging Global Issue" (1998) OECD (OECD 1998 Report) https://doi.org/10.1787/9789264162945-en (accessed 23 September 2021); OECD, "Towards Global Tax Co-operation: Report to the 2000 Ministerial Council Meeting and Recommendations by the Committee on Fiscal Affairs: Progress in Identifying and Eliminating Harmful Tax Practices" (2000) OECD (OECD 2000 Progress Report); OECD, "The OECD's Project on Harmful Tax Practices: The 2001 Progress Report” (2001) OECD (OECD 2001 Progress Report); OECD, "The OECD's Project on Harmful Tax Practices: Consolidated Application Note: Guidance in Applying the 1998 Report to Preferential Tax Regimes" (2004) OECD (CAN 2004); OECD, “The OECD's Project on Harmful Tax Practices: The 2004 Progress Report" (2004) OECD (OECD 2004 Progress Report); OECD, "The OECD's Project on Harmful Tax Practices: 2006 Update on Progress in Member Countries" (2006) OECD (OECD 2006 Progress Report); OECD, "Global Forum on Transparency and Exchange of Information for Tax Purposes" https://www.oecd.org/ tax/transparency/ (accessed 6 April 2021); OECD, Countering Harmful Tax Practices More Effectively, Taking into Account Transparency and Substance, Action 5-2015 Final Report (OECD/G20 Base Erosion and Profit Shifting Project, OECD Publishing, Paris, 2015) http://dx.doi.org/10.1787/9789264241190-en (accessed 6 April 2021) (2015 Action 5 Final Report); OECD, "BEPS Action 5 on Harmful Tax PracticesTerms of Reference and Methodology for Conduct of the Peer Reviews of Action 5 Transparency Framework" (February 2017) OECD/G20 Base Erosion and Profit Shifting Project http://www.oecd.org/tax/beps/beps-action-5-harmful-tax-practices -peer-review-transparency-framework-2017-2020.pdf (accessed 6 April 2021) (OECD 2017 Terms of Reference and Methodology for Conduct of Peer Reviews); OECD, 
book engages in a critical voyage of discovery of how the OECD is dealing with the phenomenon of tax competition and sums up its approach as prohibitory. The EU supports this approach aimed at merely curbing tax competition through discouraging or prohibiting "harmful" tax competition. ${ }^{3}$ However,

Harmful Tax Practices-Peer Review Reports on the Exchange of Information on Tax Rulings: Inclusive Framework on BEPS: Action 5 (OECD/G20 Base Erosion and Profit Shifting Project, OECD Publishing, Paris, 2017) http://dx.doi.org/10.1787/ 9789264285675-en (accessed 6 April 2021) (OECD Peer Review Reports on the Exchange of Information of Tax Rulings); OECD, Harmful Tax Practices-2017 Peer Review Reports on the Exchange of Information on Tax Rulings: Inclusive Framework on BEPS: Action 5 (OECD/G20 Base Erosion and Profit Shifting Project, OECD Publishing, Paris, 2018) https://doi.org/10.1787/9789264309586-en (accessed 6 April 2021) (OECD 2017 Peer Review Reports on the Exchange of Information on Tax Rulings); OECD, Harmful Tax Practices-2018 Peer Review Reports on the Exchange of Information on Tax Rulings: Inclusive Framework on BEPS: Action 5 (OECD/G20 Base Erosion and Profit Shifting Project, OECD Publishing, Paris, 2019) https://doi.org/10.1787/7cc5b1a2-en (accessed 6 April 2021) (OECD 2018 Peer Review Reports on the Exchange of Information on Tax Rulings); OECD, Harmful Tax Practices-2019 Peer Review Reports on the Exchange of Information on Tax Rulings: Inclusive Framework on BEPS: Action 5 (OECD/G20 Base Erosion and Profit Shifting Project, OECD Publishing, Paris, 2020) https://doi.org/10.1787/afd1bf8c-en (accessed 6 April 2021) (OECD 2019 Peer Review Reports on the Exchange of Information on Tax Rulings); OECD, "BEPS Action 5 on Harmful Tax Practices-Transparency Framework: Peer Review Documents" (February 2021) https://www.oecd.org/tax/ beps/beps-action-5-harmful-tax-practices-peer-review-transparency-framework.pdf (accessed 6 April 2021); OECD, Harmful Tax Practices - 2017 Progress Report on Preferential Regimes: Inclusive Framework on BEPS: Action 5 (OECD/G20 Base Erosion and Profit Shifting Project, OECD Publishing, Paris, 2017) http://dx.doi .org/10.1787/9789264283954-en (accessed 6 April 2021) (OECD 2017 Progress Report on Preferential Regimes); OECD, Harmful Tax Practices-2018 Progress Report on Preferential Regimes: Inclusive Framework on BEPS: Action 5 (OECD/ G20 Base Erosion and Profit Shifting Project, OECD Publishing, Paris, 2019) https:// doi.org/10.1787/9789264311480-en (accessed 22/12/2020) (OECD 2018 Progress Report on Preferential Regimes); OECD, "Harmful Tax Practices-Peer Review Results INCLUSIVE FRAMEWORK ON BEPS: ACTION 5 Update (as of August 2021)" https://www.oecd.org/tax/beps/harmful-tax-practices-peer-review-results-on -preferential-regimes.pdf (accessed 6 April 2021); OECD, "BEPS Actions", https:// www.oecd.org/tax/beps/beps-actions/ (accessed 23 August 2021); OECD, "Action 5: Harmful Tax Practices" http://www.oecd.org/tax/beps/beps-actions/action5/ (accessed 6 April 2021).

3 Above n 2; Commission, "Communication from the Commission to the Council: Towards tax co-ordination in the European Union-A package to tackle harmful tax competition" (1 October 1997) COM (97) 495 final (COM (97)); Council, "Conclusions of the ECOFIN Council Meeting on 1 December 1997 concerning taxation policy-Resolution of the Council and the Representatives of the Governments of Member States, meeting within the Council of 1 December 1997 on a code of conduct for business taxation-Taxation of saving" [1998] OJ C 002 (ECOFIN 1998); Council, 
this book argues that, in an asymmetrical global context where states are not equally situated, the approach to tax competition ought to be regulatory rather than merely curbing or prohibitory.

"Council Conclusions of 9 March 1998 concerning the establishment of the Code of Conduct Group (business taxation)" [1998] OJ C 99 (EU Code of Conduct Group Establishment); Code of Conduct Group (Business Taxation), "Report from: Code of Conduct Group (Business Taxation) to: ECOFIN Council on 29 November 1999Subject: Code of Conduct (Business Taxation)" (23 November 1999) SN 14313/99 (EU Code of Conduct Report 1999); European Council-Council of the European Union, "Code of Conduct Group (Business Taxation)" EU http://www.consilium.europa.eu/ en/council-eu/preparatory-bodies/code-conduct-group/ (accessed 6 April 2021) (EU Code of Conduct Group website). 


\section{$1.1 \quad$ PURPOSE AND LIMITATIONS}

Arguably, the anti-tax competition literature sits on one side of the debate, ${ }^{4}$ while the pro-tax competition literature situates on the other. ${ }^{5}$ Furthermore, Faulhaber observes as follows: ${ }^{6}$

There is no agreement in the economic or legal literature as to what is meant by tax competition, whether tax competition is taking place, what (if anything) is harmful about tax competition, whether tax competition should be limited, and, if so, how it could or should be limited.

Hence, the purpose of this book is to suggest what the approach to tax competition should be globally. It is a systematic and in-depth analysis of the OECD's approach, as supported by the EU, to tax competition. This book provides a critical review of the OECD's approach and proposes a deeply informed alternative approach.

4 Peggy B. Musgrave, "Merits and Demerits of Fiscal Competition" in Peggy B. Musgrave (ed), Tax Policy in the Global Economy: Selected Essays of Peggy B. Musgrave (Edward Elgar, Cheltenham (UK), 2002) 338 at 353; Peggy B. Musgrave, "Interjurisdictional coordination of taxes on capital income" in Peggy B. Musgrave (ed), Tax Policy in the Global Economy: Selected Essays of Peggy B Musgrave (Edward Elgar, Cheltenham (UK) 2002) 279 at 296, 303-305; Peggy B. Musgrave, "Comments in Session on 'Foreign Reactions to U.S. Tax Reforms"' (1988) 41 National Tax Journal 365 at 365, 366; Reuven S. Avi-Yonah, "Globalization, Tax Competition, and the Fiscal Crisis of the Welfare State" (2000) 113 Harvard Law Review 1573 at 1575-1576, 1578-1579, 1586-1596, 1597-1603, 1604-1625, 1626-1631, 1666-1674; Reuven S. Avi-Yonah, "Globalization, Tax Competition and the Fiscal Crisis of the Welfare State: A Twentieth Anniversary Retrospective" (29 May 2019) SSRN https:// ssrn.com/abstract=3367340 (accessed 16 April 2021); Steven A. Dean, "Philosopher Kings and International Tax: A New Approach to Tax Havens, Tax Flight, and International Tax Cooperation" (2007) 58 Hastings Law Journal 911 at 913, 916-917, 923-931, 934-937, 957-960, 963-964; Peter Dietsch, Catching Capital: The Ethics of Tax Competition (Oxford University Press, New York, 2015) at 25, 26, 27, 31,32 (see generally chapters 1 and 2 of the book); Carlo Pinto, Tax Competition and EU Law (Eucotax Series on European Taxation: Vol 7, Kluwer Law International, The Hague, 2003) at 372-375, 394-416.

5 Julie Roin, "Competition and Evasion: Another Perspective on International Tax Competition" (2001) 89 Georgetown Law Journal 543 at 544, 545, 549, 550-553, 554-567, 568-585, 594-604; David Elkins, "The Merits of Tax Competition in a Globalized Economy" (2016) 91 Indiana Law Journal 905 at 915, 916-937, 942-946, 947-954; Tsilly Dagan, International Tax Policy: Between Competition and Cooperation (Cambridge Tax Law Series, Cambridge University Press, Cambridge, 2018) at 1, 2, 3, 4, 213, 215, 216-221, 223, 224, 225, 229-230, 231-244.

6 Lilian V. Faulhaber, "The Trouble with Tax Competition: From Practice to Theory" (2018) 71 Tax Law Review 311 at 315. 
The book reframes the debate to find out what should be the approach to tax competition in an asymmetrical global context. The re-couching of the debate is particularly relevant and novel, given the international and global nature of the phenomenon of tax competition. Arguably, the book employs a contextualist philosophy to analyse tax competition, unlike the current OECD and EU leading approach, which adopts a purist philosophy. ${ }^{7}$ The current global society is asymmetrical rather than symmetrical. It is made up of developed and developing states, high-income states and low-income states, wealthy and poor states. Therefore, adopting a purist philosophy to analysing a phenomenon that affects the global society is not apt. The approach to such a phenomenon ought to consider the context of the global society. Contextualism ought to be the philosophy guiding the approach to such a phenomenon that affects the global society. Hence, the book is novel for at least two major reasons: (1) its redefining of the debate on tax competition, and (2) its adoption of contextualism rather than purism in its analysis.

Notwithstanding, this book is restricted to the context of the OECD's works, which concern tax competition regarding corporate income taxation or business income taxation. ${ }^{8}$ Therefore, tax competition regarding other forms of taxes, such as value added tax (VAT), is not investigated. However, the ideas emanating from the book may be relevant to tax competition concerning other forms of taxes.

\subsection{THE CRUX}

Tax competition is the crux of this book. ${ }^{9}$ Hence, this section explores and explains the emergence of tax competition. It spells out factors that have made tax competition prominent or apparent. The aim is to argue that tax competition has emerged because of exogenous and endogenous factors that persist globally. Furthermore, the section explores and examines the meaning of tax

7 Arthur Cockfield, "Purism and Contextualism within International Tax Law Analysis: How Traditional Analysis Fails Developing Countries" (2007) 5 eJournal of Tax Research 199 at 199-224 (on the dichotomy between the purist and contextualist analysis of international tax law).

8 OECD 1998 Report, at 8 [6 and 7]; 2015 Action 5 Final Report, at 11 [2 and 3], 12 [4], 19 [11 and 12].

9 Tax competition is used interchangeably with international tax competition in this book. There can also be tax competition in a federal state like the US, where units within and constituting the state also have fiscal powers. See Roin, "Competition and Evasion: Another Perspective on International Tax Competition" (2001), at 546, n 9. See also Wolfgang Schön (ed), Tax Competition in Europe (European Association of Tax Law Professors, IBFD, Amsterdam, 2003) (for tax competition within some European states). 
competition. Hence, the section additionally submits that tax competition is a government behavioural concept and clarifies the other commonalities in the meaning of tax competition.

\subsubsection{The Emergence of Tax Competition}

Capital mobility across states and capital neutrality are two factors identified in the literature leading to the emergence of tax competition. Since the end of World War II, there has been an expansion of opportunities for cross-border economic activities as a result of influences that include the gradual relaxation of capital controls in developed states. ${ }^{10}$ Together with globalisation and technological advancement, this relaxation has increased the mobility of capital, giving rise to tax competition and issues of taxation of income from mobile capital. ${ }^{11}$ However, issues in the taxation of cross-border income predate globalisation, which has only increased the effects of these issues in the taxation of cross-border income. ${ }^{12}$ Capital has, therefore, been regarded as the most mobile factor of production. ${ }^{13}$ Mobility here does not require the movement of the owners of capital, and the capital is used by multinational enterprises (MNEs), which may operate simultaneously in more than one

10 Andrew P. Morriss and Lotta Moberg, "Cartelizing Taxes: Understanding the OECD's Campaign against 'Harmful Tax Competition"' (2012) 4 Columbia Journal of Tax Law 1 at 24-25.

11 OECD 1998 Report, at 13-14 [20-23]; Avi-Yonah, "Globalization, Tax Competition, and the Fiscal Crisis of the Welfare State" (2000), at 1575, 1576; George M. Melo, "Taxation in the Global Arena: Preventing the Erosion of National Tax Bases or Impinging on Territorial Sovereignty? (A Critique of the OECD's Report: 'Harmful Tax Competition: An Emerging Global Issue')" (2000) 12 Pace Int'l Law Review 183 at 193-194; Alexander Townsend, Jr, "The Global Schoolyard Bully: The Organisation for Economic Co-operation and Development's Coercive Efforts to Control Tax Competition" (2001) 25 Fordham Int'l Law Journal 215 at 219, 231-234. See also William B. Barker, "The Tax Cuts and Jobs Act of 2017: The SALT Deduction, Tax Competition, and Double Taxation" (2019) 56 San Diego Law Review 73 at 100-102 (tax competition among constituent states of the US flourishes under certain conditions. These conditions include the mobility of a factor of production, such as capital.); Michael P. Devereux, Ben Lockwood and Michela Redoano, "Do countries compete over corporate tax rates?" (2008) 92 Journal of Public Economics 1210 at 1213 (finding that evidence for tax competition is much stronger between states without capital controls in place).

12 Roin, "Competition and Evasion: Another Perspective on International Tax Competition" (2001), at 544.

13 Peggy B. Musgrave, "Fiscal Coordination and Competition in an International Setting" in Peggy B. Musgrave (ed), Tax Policy in the Global Economy: Selected Essays of Peggy B Musgrave (Edward Elgar, Cheltenham (UK), 2002) 308 at 315. 
state. ${ }^{14}$ Consequently, the fiscal treatment of capital and capital income is a major international issue. ${ }^{15}$

The "capital neutrality paradox" theory avers that the focus on capital neutrality by the tax laws of wealthy developed states has, in part, given rise to tax competition. ${ }^{16}$ Capital neutrality here is a situation where the tax laws of a state make it cheaper and easier for capital to leave the state, for example, by reducing double taxation on cross-border investment to increase gains from cross-border trade. ${ }^{17}$ In other words, cross-border trade gives rise to tax laws focusing on capital neutrality to encourage the trade, and this focus, in part, gives rise to tax competition. The paradox of the capital neutrality is that developed states represented by the OECD discourage tax competition; but their domestic tax laws make it cheaper for capital to move, thereby encouraging tax competition. The next subsection examines the meaning of tax competition.

\subsubsection{The Meaning of Tax Competition}

Despite the variety of definitions of tax competition in the literature, this subsection seeks to explore, highlight and reinforce the idea from the literature that tax competition is a government behavioural concept, i.e. fiscal behaviours of states through the instrumentality of governments. Therefore, this book regards tax competition as the ways in which states use fiscal measures to attract and retain potentially taxable events, which include capital flows and business investments within their tax jurisdictions.

14 Musgrave, "Fiscal Coordination and Competition in an International Setting" (2002), at 315 .

15 Musgrave, "Fiscal Coordination and Competition in an International Setting" (2002), at 315 .

16 Adam H. Rosenzweig, "Why are There Tax Havens?" (2010) 52 William and Mary Law Review 923 at 923, 930, 931, 932, 933, 935, 936, 943, 944, 945, 980, 981. See also Thomas Rixen, The Political Economy of International Tax Governance (Transformations of the State Series, Palgrave Macmillan, UK, 2008) at 186: “... tax competition is not exogenously given, but endogenously constituted and shaped by the rules of international taxation".

17 Rosenzweig, “Why are There Tax Havens?” (2010), at 930-931, 932, 933, 935, 936, 943, 944, 945, 980, 981. See also OECD, Model Tax Convention on Income and on Capital: Condensed Version (as it read on 21 November 2017) (OECD Publishing, 2017) https://read.oecd-ilibrary.org/taxation/model-tax-convention-on-income-and-on -capital-condensed-version-2017_mtc_cond-2017-en\#page74 (accessed 7 April 2021) at 72 [54] of the commentary on art 1 (on the principal purpose of double taxation conventions being inter alia to promote the exchange of goods and services, as well as the movement of capital) (OECD 2017 Model DTT). 
Ring defines tax competition as "a country using its tax system to attract investment, business activity, or cash flow to the country itself'. ${ }^{18}$ Elsewhere, she states: ${ }^{19}$

In its broadest conception the phrase captures a country's use of any feature of its tax system to "enhance" its competitive advantage in the marketplace for capital, investment, and/or nominal business presence. The tax features readily susceptible to enlistment in this mission include tax rates, tax base, administrative system, transparency, disclosure, information sharing, and special credits, exemptions and deduction.

Ring's second definition seems to be a broad definition of this government behavioural concept because she employs the words, "country's use of any feature of its tax system". However, the use of the word "attract" in her first definition narrows its meaning by suggesting that tax competition seeks only to draw capital into a particular state. As well as attracting capital, tax competition can also imply the retention of capital, especially when capital neutrality policies are in existence in other states. ${ }^{20}$ These capital neutrality policies, which give relief for double taxation on cross-border business and investment, ${ }^{21}$ presuppose that the cross-border investment has already been made, i.e. the capital has already been attracted. Where the capital has already been "attracted", the next objective ought to be retaining such capital within the host state. Furthermore, tax competition enhances not only the competitive advantage of a state for "nominal business presence", but it may also enhance a state's competitive advantage for positive externalities or "substantial business presence". ${ }^{22}$

18 Diane M. Ring, "What's at Stake in the Sovereignty Debate?: International Tax and the Nation-State" (2008) 49 Virginia Journal of International Law 155 at 184.

19 Diane M. Ring, "Democracy, Sovereignty and Tax Competition: The Role of Tax Sovereignty in Shaping Tax Cooperation" (2009) 9 Florida Tax Review 555 at 561-562.

20 Rosenzweig, "Why are There Tax Havens?" (2010), at 923, 930, 931, 932, 933, 935, 936, 943, 944, 945, 980, 981 (on the "capital neutrality paradox" theory); William B. Barker, "Optimal International Taxation and Tax Competition: Overcoming the Contradictions" (2002) 22 Northwestern Journal of International Law and Business 161 at 172 ("Typically, tax competition is a purposeful activity that nations engage in to attract or retain activity").

21 Rosenzweig, "Why are There Tax Havens?" (2010).

22 Faulhaber, "The Trouble with Tax Competition: From Practice to Theory" (2018), at 316, n 21. 


\section{According to Roxan: ${ }^{23}$}

The term "tax competition" has come to be used in a very general way to denote the international pressures faced by a national government in devising tax policy. In particular the term refers to the pressure to reduce the level of tax charged in respect of certain types of income, commodity or activity to the levels prevailing in other countries. [emphasis added]

Roxan analyses this government behavioural concept from the perspective of international pressures. In addition to international pressures, states may also face domestic pressures when "devising" tax policies. For example, there is the pressure to favour resident taxpayers making domestic investments and the pressure to retain foreign investments already within states' jurisdictions. ${ }^{24}$

Englisch and Yevgenyeva describe tax competition as: ${ }^{25}$

... a process of uncooperative but interdependent setting of tax rates between jurisdictions that enjoy tax autonomy, in a bid for investments, other economically relevant activities or resources, or mere profits. [emphasis added]

This description re-echoes the government behavioural concept but focuses on tax rates. ${ }^{26}$ The setting of tax rates as used in the description narrows the meaning of tax competition as it is only one of the ways by which states attract and retain investments via taxation policy. ${ }^{27}$

Dietsch defines tax competition as "... the interactive tax setting by independent governments in a noncooperative, strategic way". ${ }^{28}$ This definition

23 Ian Roxan, "National Report United Kingdom" in Wolfgang Schön (ed), Tax Competition in Europe (European Association of Tax Law Professors, IBFD, Amsterdam, 2003) 479 at 479.

24 Morriss and Moberg, "Cartelizing Taxes: Understanding the OECD's Campaign against 'Harmful Tax Competition"” (2012), at 12: "nations play quite different 'games' in their tax policies. Some are attempting to attract investment to locations lacking resources; others seek to capitalize on the value of their national advantages".

25 Joachim Englisch and Anzhela Yevgenyeva, "The 'Upgraded' Strategy Against Harmful Tax Practices Under the BEPS Action Plan” (2013) British Tax Review 620 at 621.

26 Englisch and Anzhela Yevgenyeva, "The 'Upgraded' Strategy Against Harmful Tax Practices Under the BEPS Action Plan" (2013), at 621: "International tax competition occurs between sovereign nations or territories".

27 Morriss and Moberg, "Cartelizing Taxes: Understanding the OECD's Campaign against 'Harmful Tax Competition"” (2012), at 12: "Differences in definitions can form yet another species of tax competition. For example, 'dividends' are defined differently by tax laws in different countries and this can result in either over-taxation or under-taxation of a particular payment".

28 Dietsch, Catching Capital: The Ethics of Tax Competition (2015), at 2, 36. 
also evidences that tax competition is what states do through their governments. However, Dietsch's definition appears to negate the possibility of the coexistence of co-operation and tax competition. Arguably, this coexistence is possible, especially where tax competition is regarded as a form of regulatory competition. This argument is taken further in Chapter 5 of this book, under the heading "Objectives in the Regulation of Tax Competition". ${ }^{29}$

Morriss and Moberg view tax competition within the context of states competing: ${ }^{30}$

... for economic activity in multiple ways, including offering different mixes of security of ownership, access to resources, regulatory climates, and demands on investors to share resources. Tax competition is but one aspect of this competition. [emphasis added]

Even though tax competition here is regarded as an aspect of competition for economic activity by states, the definition is not limited to the competition via the fixing of tax rates. The definition also shows that a common ground running through definitions given to tax competition is that it is a government behavioural concept.

Griffith and Klemm argue as follows: ${ }^{31}$

"Tax competition" can refer to many different processes. We use it to describe the phenomenon that countries lower their corporate income taxes in order to attract the real activities of firms. There is also competition for taxing rights, i.e. competition for having profits reported in a particular country, without any associated movement of production. Whenever we refer to the latter in this paper, we will clarify this by using the term competition for "paper profits" or "taxing rights". [emphasis added]

By using the word "attract", Griffith and Klemm also omit the possibility that tax competition can be used to retain investment already within a state. These economists restrict competition for taxing rights to competition for paper profits, which are profits booked for a location in the tax books or records, without any actual activity or real investment in that location. However, there is a convincing argument that competition for taxing rights may also entail

\footnotetext{
29 Below at sub-subs 5.2.1.3.

30 Morriss and Moberg, "Cartelizing Taxes: Understanding the OECD's Campaign against 'Harmful Tax Competition"” (2012), at 5, 9-15.

31 Rachel Griffith and Alexander Klemm, "What Has Been the Tax Competition Experience of the Last 20 Years?" (2004) Institute for Fiscal Studies and University College London Paper WP04/05 1 at 4-5: also available in (2004) 34 Tax Notes Int'1 1299 (Special Supplement).
} 
competition by states for actual or real investments to a location, including profits arising from such real investments. ${ }^{32}$

Hence, it is submitted that tax competition is premised on commentators observing both the formulation of domestic tax policies and the operation of tax laws in an increasingly integrated world economy. Musgrave regards tax competition as "interjurisdictional fiscal competition". ${ }^{33}$ Roin views tax competition as a type of "intergovernmental competition". ${ }^{34}$ Thus, a common ground running through the varying definitions of tax competition is that it is a government behavioural concept, i.e. what states do through their governments.

However, it must be noted that these definitions vary along the line of the object(s) of this government behavioural concept. The variety of objects include: investment; business activity; cash flow; capital; nominal business presence; certain types of income, commodity or activity; economically relevant activities or resources; economic activity; real activity; and paper profits. Though Dietsch's definition stops short of identifying the object(s) of this government behaviour, he notes that it is a strategic behaviour. This book regards these objects of tax competition as potentially taxable events as evinced in the way the book defines tax competition at the beginning of this subsection.

Furthermore, these definitions also evidence that tax competition has elements. Elements of tax competition are the ways by which the national fiscal system attracts and retains factors of production or potentially taxable events to fall and remain respectively within its taxing jurisdiction voluntarily. Examples of these elements include tax rates (statutory tax rates and effective tax rates), tax base definition, tax incentives and administrative practices. States continue to employ these elements of tax competition.

In summary, tax competition is a government behavioural concept that has become readily perceived because of capital mobility (exogenous-non-tax factor) and the "capital neutrality paradox" (endogenous-tax factor). These exogenous and endogenous factors persist in the global society. There are also

32 Kimberly A. Clausing, "The Effect of Profit Shifting on the Corporate Tax Base in the United States and Beyond" (2016) 69 National Tax Journal 905 at 914: "some real economic operations may be required in order to shift income, and the ability to shift income to low-tax destinations increases the attractiveness of such destinations as bases for real activity"; IMF, "IMF Policy Paper: Spillovers in International Corporate Taxation" (9 May 2014) https://www.imf.org/external/np/pp/eng/2014/050914.pdf (accessed 14 April 2021) at 21 [26] (arguing that "tax competition is driven at least as much by profit-shifting concerns, ... as by the desire to attract real investments") (IMF 2014).

33 Musgrave, "Merits and Demerits of Fiscal Competition" (2002), at 352.

34 Roin, "Competition and Evasion: Another Perspective on International Tax Competition" (2001), at 545-546. 
objects and elements of tax competition. The following section outlines the book's contribution to knowledge regarding tax competition.

\subsection{CONTRIBUTION TO KNOWLEDGE}

This book analyses from the perspective of the effects of tax competition. As supported by the EU, the OECD takes a prohibitory approach to tax competition by classifying certain government behaviours as "harmful" tax competition and taking steps to discourage, prohibit or merely counteract them. ${ }^{35}$ This classification presupposes that there is another class, namely "beneficial" tax competition. Thus, the OECD's prohibitory approach retains a difference between "harmful" tax competition and "beneficial" tax competition. This book rejects such a distinction as it is fundamentally illogical. It is submitted in this book that these classifications are misnomered, clumsy and contradictory. Government behaviours classified as "harmful" tax competition do have beneficial and harmful effects. Similarly, government behaviours classified as "beneficial" tax competition also have harmful and beneficial effects. Hence, the book submits that a better analysis ought to proceed from tax competition in the context of its potential effects, harmful and beneficial.

The book argues for a regulatory approach to tax competition denoting the wide meaning of regulation. This deeply informed alternative approach is based on the normative ground of fiscal sovereignty of states viewed from the perspectives of right and duty in the global context. Thus, the book submits that the key principle or concept that should be driving the approach to tax competition globally and internationally should be fiscal sovereignty taken in the context of right and duty. States should have a right to determine their domestic tax policies (matters) autonomously, but they should also have a duty to respect the right of other states via co-operation. In the context of tax competition, the manner of co-operation matters because of its mixed effects and the asymmetrical global society. Therefore, the book suggests a regulatory type of co-operation that is neither merely restrictive nor necessarily prohibitory. The book proposes the explicit modification and expansion of the objectives, as well as the functions of double tax treaties (DTTs), as exemplified in the OECD model DTT, to include the regulation of tax competition. It proposes the regulation of tax competition via disclosure. Through DTTs that adopt the proposed regulatory approach to tax competition, the right and duty of fiscal sovereignty can be made compatible. In the future, the proposed regulatory approach to tax competition may be adopted in a multilateral instrument, but

35 Below at $\mathrm{Ch} 2$ of this book. 
DTTs are readily available to commence the regulation of tax competition globally.

The book supports the notion that global redistribution should be part of the objectives and functions of international tax policy, correcting market failure or unjust distribution in an asymmetrical global society where relatively few states have wealth concentration. In this context, the regulatory approach to tax competition as proposed in this book is preferred to the OECD's prohibitory approach. Given the beneficial effects of tax competition, the proposed regulatory approach allows for the redistribution of wealth from the few wealthy states to the numerous poor states. The proposed regulatory approach is a more pragmatic approach that may allow for the alignment of sovereign interests and create room for adoption in a regulatory framework. The proposed regulatory approach explicitly encourages and restricts tax competition, i.e. adopts the wide meaning of the regulation of tax competition, and, therefore, increases the chances of adoption in DTTs. On the other hand, the OECD's prohibitory approach appears to favour developed and wealthy states. This approach is likely to disadvantage the global redistribution of wealth (global redistributive justice). Hence, the OECD's prohibitory approach appears not to create a platform where the interests of developed states will align with the interests of developing states to allow for the compatibility of right and duty of fiscal sovereignty in a regulatory framework. The OECD's prohibitory approach may prove too difficult to adopt in DTTs because it merely restricts or discourages tax competition, which has beneficial effects that may be in the national interests of states.

\section{$1.4 \quad$ STRUCTURE}

The subsequent chapters of the book are in the following order. Chapter 2 conceptualizes the OECD's approach, as supported by the EU, to tax competition. It argues that the OECD's policy approach, as supported by the EU, is prohibitory of tax competition. The OECD employs certain factors (no or nominal taxation on corporate income; lack of effective exchange of information; lack of transparency; lack of substantial activity; and ring-fencing) in identifying states, and aspects of tax systems of states, as tax havens and harmful preferential tax regimes respectively. According to the OECD, these tax havens and harmful preferential tax regimes are "harmful" tax competition, which it seeks to discourage, curb and counteract. As supported by the EU, the OECD also employs mechanisms to curb, counteract, discourage and eliminate "harmful" tax competition identified in the chapter. These implementation techniques are peer reviewing and blacklisting. The OECD's prohibitory approach, as supported by the EU, in classifying certain types of tax competition as "harmful" tax competition and taking steps to discourage such, presupposes or connotes 
that there is "beneficial" tax competition. The chapter further argues that these classifications are misnomered, clumsy and contradictory because both classifications have beneficial and harmful effects. It concludes that it is fundamentally illogical to divide tax competition in such a manner. Alternatively, it may be a Herculean task to create a logical distinction. Therefore, the book prefers to analyse tax competition from the perspective of its effects.

Chapter 3 argues that tax competition has potentially harmful and beneficial effects. The potentially harmful effects investigated in this chapter are tax avoidance and evasion; erosion of tax base; inequity; inefficiency; distortion of investment patterns and the decrease in global welfare; free-riding; and the race to the bottom regarding the corporate income tax. Careful analysis evinces that: these harmful effects have been overstated in some instances; can be rebutted in some other instances; and can be mitigated without necessarily adopting a prohibitory approach to tax competition. Therefore, the chapter submits that these harmful effects are not sufficient grounds for adopting a prohibitory approach to tax competition. In any event, there are beneficial effects of tax competition to states, tax systems and taxpayers. The potentially beneficial effects investigated in this chapter are: efficiency; inter-nation equity (redistribution at the global level); national economic growth; reduction in the potential over-taxation of foreign taxpayers; and the democratic choice of taxpaying voters.

Chapter 4 argues that the normative grounding for tax competition, as well as for determining a global approach for the phenomenon of tax competition, can be established in the context of sovereignty. The literature evinces that sovereignty has a meaning that includes right and duty. Given that the book concerns tax competition, Chapter 4 focuses on the tax aspect of sovereignty, i.e. fiscal sovereignty in the sense of right and duty. This book regards the right as the right of fiscal sovereignty, while the duty is regarded as the duty of fiscal sovereignty. Therefore, fiscal sovereignty is the legal-normative reason for tax competition and can also be the normative grounding for the regulatory approach to tax competition that denotes a wide meaning of regulation. The chapter submits that the right of fiscal sovereignty can be grounded in social contract theory, the origin of sovereignty and social construct theory. The chapter also submits that there are coherent grounds for the duty of fiscal sovereignty in the context of tax competition. Principles and theories relied upon for this duty of fiscal sovereignty are: "global social contract"; neighbourliness (supported by the principle of non-interference); human rights; international law; inter-nation equity (need for global redistribution); and global fiscal interdependence (supported by the spillover argument). However, it is submitted that of all these principles and theories, international law (e.g. treaty) is the most coherent ground. Furthermore, the chapter submits that the right of fiscal 
sovereignty and duty of fiscal sovereignty can be compatible with each other, even in the context of tax competition.

Chapter 5 argues that the approach that ought to be taken regarding tax competition is a regulatory approach. Thus, it suggests that the OECD ought to shift from its prohibitory approach to the proposed regulatory approach. This regulatory approach denotes adopting the wide meaning of regulation of tax competition on well-grounded raison d'être; incorporating this wide meaning into a regulatory framework such as the network of DTTs via the OECD model DTT; and adopting a mode of regulation in DTTs (e.g. regulation via disclosure) that represents the wide meaning of regulation of tax competition. The chapter distinguishes the OECD's prohibitory approach from the suggested regulatory approach to tax competition. It also investigates the weaknesses and strengths of the proposed regulatory approach to tax competition.

Chapter 6 concludes the book and notes areas for future research regarding tax competition. 